\title{
わが国の近代鋼橋梁に関する画像データベースのCD－R O M化 \\ CD-ROM products of the image database on modern steel bridges in Japan
}

\author{
北村潤一*，岡林隆敏** \\ 小西純一***, 西森英海 ${ }^{*}$
}

\section{[abstract]}

By Junnichi KITAMURA,TakatoshiOKABAYASHI, Junnichi KONISHI,Hidemi NISHIMORI

The investigating committee of historical steel bridge investigated modern steel bridges in Japan, and compiled these data. In this study, we construct the image database which are made up specifics of bridge photographs, drawings and a map. This database can be refered the object bridge by the specifics of the bridges and maps of construction places. The database is developed by Visual Basic4.0, and installed CD-ROM database for practical use in public.

\section{1.はじめに}

現在、土木学会鋼構造委員会歷史的鋼橋調査小委員会では、全国に残されている土木技術史の上で 重要である鋼橋の調査を実施しており「歴史的銅橋集覧」にまとめている。しかし、調查資料は多様、 かつ膨大であるため特定の橋梁を検索することは容易ではない。これらの貴重な資料を有効に活用す るためには文字情報や写真・図面等の画像情報をパーソナルコンピュータでデータベース化し、検索 が容易に行えるシステムをする必要がある。そこで、画像データベース化する際の重要な点法、多様 な情報を一元的に取り扱い、検索が視覚的に行えることである。本研究では、「歴史的鋼橋集覧」に 基づいて、Visual Basic Ver4.0 利用して「日本近代歴史的銅橋画像データベース」を作成し、検索 結果を得るまでの効果的なインターフエイスの設計を行った。さらに、この画像データベースを広 く活用できるようにするために配布用の CD-ROMを制作した。

\section{2. 画像データベースとインターフェイスの方針}

画像データベースとは、ある文字情報とそれに関する写真・図面などの画像を連結させ、保存・検 索するものである。また、これらの関連した情報を効率よく検索・閲覧するには、データベースを構 築する際のインターフェイスの構成が重要之 なる。そこで、デー夕を検索するためのイン ターフェイスとして地図情報など使用すれば、 視覚的な検索が可能になり、文字からの㭘索 より、使い易いデータベース構成が可能にな データベース

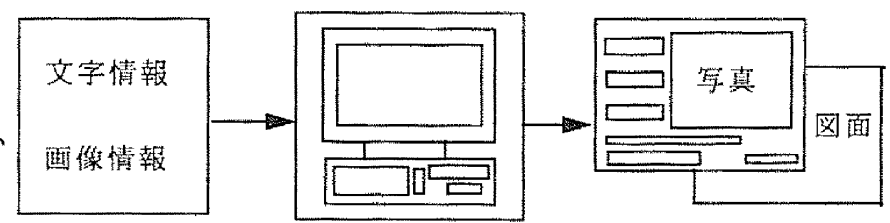

㛟索実行
恰蓕結果 る。本研究で作成した画像データベースにお 【キーワード】歴史的銅橋梁 画像データベース CD-ROM

図-1画像データベースの構成

* 学生買 長崎大学工学部社会開発工学科

( ( 852 -8521 長謂市文教町 1-14 TEL.095-847-1111)

** 正 員 長崎大学工学部社会開発工学科

(T852-8521 長踦市文教町 1-14 TEL.095-847-1111)

***正 負，信州大学工学部社会開発工学科

（T380-09522 長野市若里 500 TEL.026-226-4101） 
ける〔地図からの検索〕において全国・地方・都道府県地図を広域順に使用することで、全国の近代 歷史的鋼橋梁を直感的で視覚的な検索が可能となった。さらに、検索結果は文字情報と写真・図面・ 詳細地図といった様々な情報形態を一元的に表示されるよう設計した。図-1に画像データベースの構 成を示す。

\section{Visual Basic による橋梁データベースの構築 (1) (2) (3)}

(1) Visual Basic

本研究で使用したソフトは、Visual BasicVer4.0 (Microsoft 社製)である。Visual Basic はプログラ ミングをビジュアル化した言語であり、マウスでツールバーからコントロールと呼ばれる部品をウィ ンドウに配置し、ユーザーインターフェイスを作成して、そのコントロールに処理を行うコードを記 述してアプリケーションソフトを作成してする。

(2) データベースエンジン

Visual Basic で作成するデータベースアプリケー ションの構成を図ー 2 に示す。プログラムマネージャ 一でクエリーを作成しておくと SQL（Structured Query Language）はこのクエリーと組み合わせて条 件を表示でき、単純化できる。検索手順はユーザイン ターフエイスより㭘索要求がなされ、データベースエ ンジンが必要なデー夕をデー夕群から検索を行い、そ の結果を検索画面の指定された位置に配置・表示する というものである。

(2)地図情報によるインターフェイスの設計

近年の傾向として地図情報をインターフェイスとしたデータベース の構築が行われている。本研究では対象物件を検索する方法として座標 を利用した。図-3に座標系を定義する地図情報検索画面を表示する。 まず、地図に座標系を定義しておく。そこでマウスイベントを使い、マ ウスの位置と状態を認識することができる。〔Mouse Down〕イベント ではクリックされたところの X,Y 座標が与えられるので、あらかじめデ 一タとして特定範网の座標を定義しておき、座標值を基に検索を行うプ ログラミングをした。こうして対象物件のボタンをクリックすると同時 にデータベースが開かれ、検索させることができるようになった。

4. 日本近代歴史的鎆橋画像データベース (4) (5) (6)

我が国の明治から昭和初期に架けられた歴史的な鋼橋は、技術史上、 価值が高いものが多いのにも関わらず時代が進むに連れて、架け替え が行われ年々その数が少なくなりつつある。そこで、土木学会鋼構造 委員会歷史的鋼橋調查小委員会では、全国に残されている土木技術史 の上で重要である鋼橋の調査を実施して、調査リストの作成を行った。 表-1に調查リストを示す。これらの調查結果を広く活用すために、パ ーソナルコンピュータを利用し、調査したデー夕を基に全国の歴史的 鋼橋をデータベース化することにした。本研究で作成した「日本近代

\begin{tabular}{|c|l|l|}
\hline & 橋種 & 橋数 \\
\hline 鉄道橋 & & 190 \\
\hline 道路橋 & $\begin{array}{l}\text { プレート } \\
\text { ガーダー }\end{array}$ & 53 \\
\cline { 2 - 3 } & トラス橋 & 70 \\
\cline { 2 - 3 }$ア$ アーチ橋 & 76 \\
\cline { 2 - 3 } & 吊橋 & 19 \\
\cline { 2 - 3 } & 可動橋 & 49 \\
\hline
\end{tabular}

表-1 一覧表 


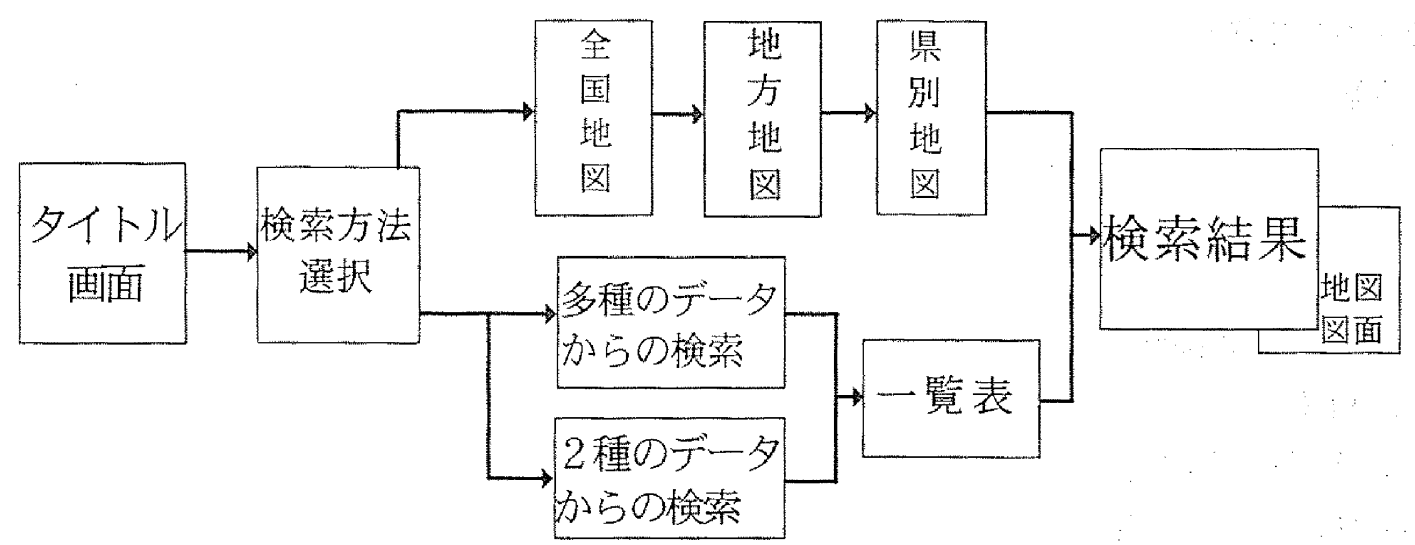

図-4 日本近代歴史的鎆橋画像データベースの構成

歴史的銅橋画像データベース」の構成を図-4に示す。

図-4の画面群に基づいて、作成した「日本近代歷史的鋼橋画像データベース」を説明する。まず、 (1)地図情報からの検索あるいは、(2)文字情報からの梌索かのどちらかを選ぶ。地図情報からの検索の 場合、画面 a の全国地図画面で地方名のボタンを押すと、地方地図画面が表扎る。都道府県名ボ夕ン を押すと画面 $\mathrm{b}$ の都道府県地図が表示され、橋梁名をクリックし画面 $\mathrm{e}$ の橋梁データが表示される。 さらに、追加データとして画面 $\mathrm{f} の$ 橋梁の図面と詳細地図の画面がある。この地図情報からの検索で は画面bの目地図には座標系が定義してあり、Mouse Down イベントで与えられる座標で検索を行っ てる。次に、文字情報からの検索の場合、画面 C で全ての検索項目（所在地・橋長・開通年月日・主

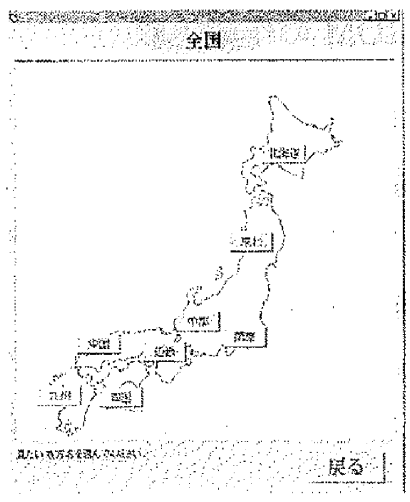

函面 a

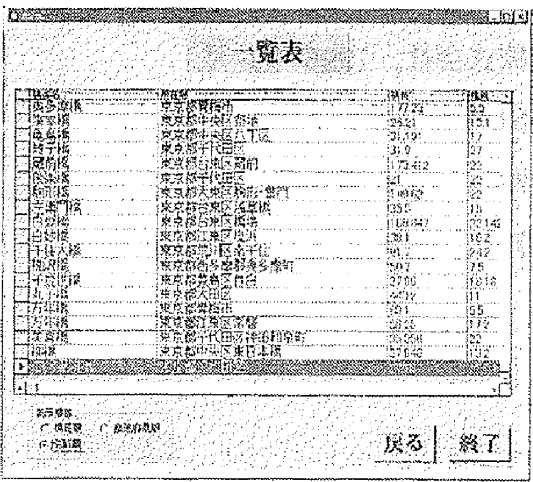

画面 $\mathrm{d}$

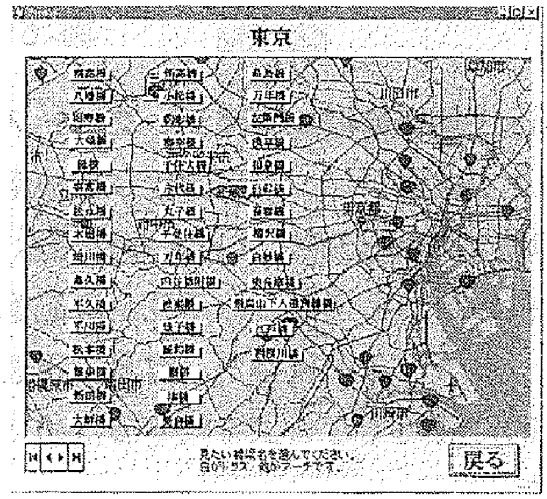

画面 $b$

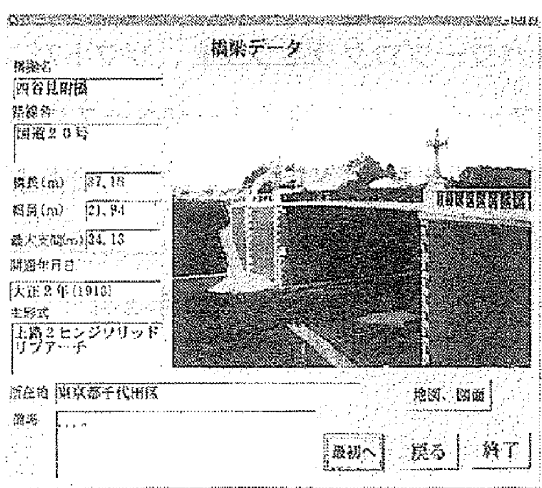

画面 $\mathrm{e}$

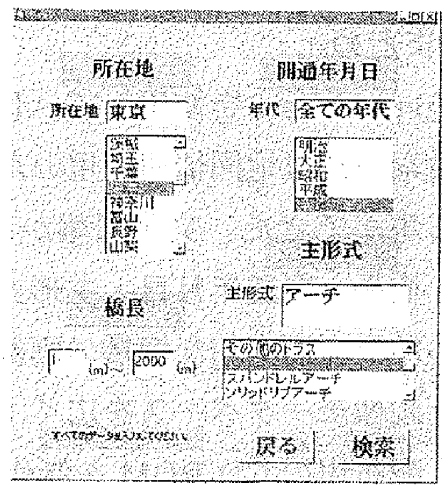

画面 $\mathrm{C}$

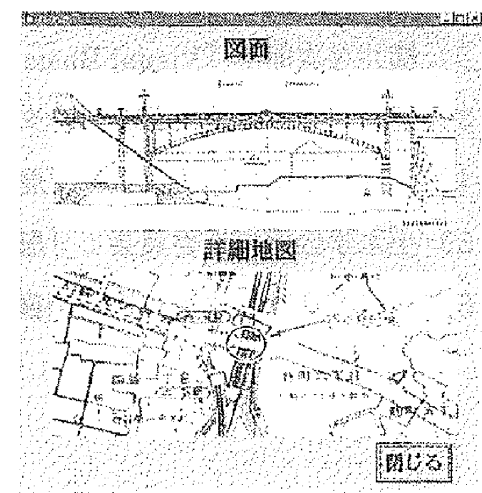

画面 $\mathrm{f}$

図-5 画像データベースの棈成画面群 
形式）を入力して検索ボタンを押すと、画面 $\mathrm{d}$ の一覧表が表示される。ここでは、橋長順・都道府県 順・五十音順にデー夕を変更表示できる。そこで橋梁を選択し、地図情報からの検索と同様の検索結 果が得られる。この結果、地図情報を用いることにより視覚的に、また、文字情報からは文字を入力 することがないので多少、記憶が曖昧でも、全国の近代歴史的鋼橋を容易にかつ迅速な検索ができる ようになった。

\section{5. 配布用ディスク制作}

作成した画像データベースを広く一般的に活用できるようにするために、Visual Basic 上で動 作する「日本近代歴史的鋼橋画像データベース」の CD-ROM 版を制作した。図ー6に CD-ROM の作成手順を示す。配布用ディスク制作において、ハードディスク、光ディスクに記憶させているプ ログラムやデータを、CD ライターを用いて、1 度だけ書き込み可能な CD Recordableに書き込む。 書き込みに使用したアプリケーションソフトは EZ-SCSI Pro4.5J（Adaptec 社製）である。しかし、 Visual Basicで作成したアプリケーションをそのまま CD-ROM に書き込んでも文字情報や画像情報 の保存場所が変わるために検索ができなくなる。そこで、CD-ROM 制作に必要なコード変更をして、 セットアッププログラムを作成しなければならない。セ ットアッププログラムは Visual Basicのセットアップ ウィザードを使用することで上記の問題を回避し、配布 用 CD-ROM を容易に作成できる。この結果、Visual Basic をインストールしていない一般的なパーソナ ルコンピュータでも「日本近代歷史的鋼橋画像デー タベース」を使用できるようになった。

6. まとめ

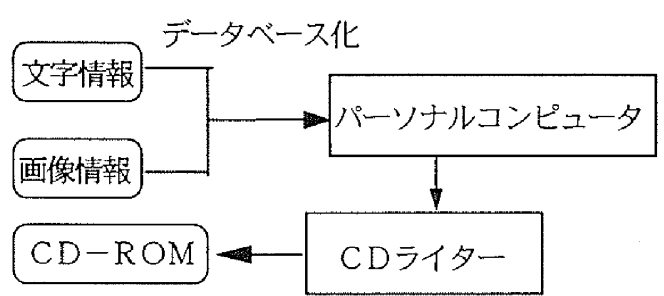

書き込み

図-6 CD-ROM の作成手順

Visual Basic を使用して「日本近代歴史的鋼橋画像データベース」を作成した。画像データベース の検索方法は地図情報を用いたことで検索がビジュアル化し、検索が容易なインターフエイスを作成 する事ができた。文字情報からの検索では文字を入力することなくポップアップメニューより所在 地・橋長・開通年月日・主形式の各項目から選択し、不完全な記憶でも検索を行うことができた。以 上の結果、歴史的な鋼橋の画像データベースの検索が、容易で迅速になった。さらに、本研究で作成 した画像データベースを広く一般的に活用できるようにするために、これを CD Recordable に書き込 み、配布用の CD-ROM を制作した。

【参考文献】

（1）新居雅行：「Visual Basic4.0 データベース構筑法」、株式会社ビー・エヌ・エヌ、1996 年 6 月

（2）横井与次郎：「Visual Basic4.0パワープログラミング」、ソフトバンク株式会社、1996 年 6 月

（3）㴔崎荘平：地図情報をインターフェイスとする画像データベースに関する研究、1997年 2 月

（4）土木学会鋼構造委員会：「歷史的鋼橋集筧（第 1 集）」、社団法人士木学会、1996 年 3 月

（5）土木学会鋼構造委員会：「歷史的鋼橋集覧（第 2 集）」、社団法人土木学会、1996 年 3 月

（6）西森英海：日本近代銅橋画像データベースの作成、1998 年 2 月 